\title{
STRATEGI DAN PENDEKATAN PELAKSANAAN BIMBINGAN KONSELING DI SEKOLAH UNTUK MENGHADAPI REVOLUSI INDUSTRI 4.0
}

\author{
Oleh : Prof. Dr. Firman. MS. Kons \\ (Jurusan Bimbingan dan Konseling Fakultas Ilmu Pendidikan Univ.Negeri Padang) \\ Email : firman@konselor.org
}

\begin{abstract}
Various activities in the community and education today are all digital, automatic and move from manual to online. This paper aims to formulate a strategy and approach to implementing school counseling in facing the 4.0 industrial revolution. Based on the discussion it can be concluded that the School Counselor / Counselor requires a new approach in preparing students / counselors to have competence and take opportunities in the changes to face the industrial revolution 4.0. The mellinial generation in the industrial revolution era 4.0 has the advantage of carrying out various activities at the same time, creative and prioritizing equality, critical and contributing in various ways. BK service programs and models needed by mellinial generation use more digital technology (online). School BK / Counselor teachers are required to have the ability to implement methods / service techniques oriented to students / counselors, with strategies, namely: encouraging and facilitating the generation of mellinial ideas -ide creative and innovative, modify ideas in giving birth to feedback, provide feedback and use information and experience formulating approaches / strategies and models of guidance and counseling services according to the needs of the next generation.
\end{abstract}

Key Words : Strategy, Approach, Counseling Guidance, Melinium 4.0

\section{A. Pendahuluan}

Dewasa ini perubahan sosial secara fundamental sedang mengubah cara hidup masyarakat Indonesia dalam berbagai segi untuk memenuhi kebutuhan hidupnya. Perubahan tersebut dipicu oleh kegiatan industri yang menggabungkan teknologi otomatisasi dengan teknologi cyber di era revolusi industri 4.0. Otomatisasi dan pertukaran data dalam teknologi manufaktur, termasuk di dalamnya sistem cyber-fisik, Internet of Things (IoT), komputasi awan serta komputasi kognitif telah merasuk dalam berbagai kegiatan masyarakat (Padmo, 2005).

Perubahan sosial yang sedang berlangsung di masyarakat, berawal dari tahun 1750-1830 di era Revolusi Industri Pertama, ditandai oleh penemuan mesin uap dan kereta api yang mampu menggantikan tenaga manusia dan hewan sebagai kekuatan produksi. Perubahan berlanjutnya di era Revolusi Industri Kedua (1870-1900), ditandai oleh penemuan listrik, alat komunikasi, bahan-bahan kimia dan minyak yang berguna untuk produksi massal. Selanjutnya di era Revolusi Industri Ketiga (1960 hingga sekarang), terjadi perubahan yang diawali oleh penemuan komputer, internet, dan telepon 
genggam yang bermanfaat untuk keberlangsungan otomatisasi proses produksi dalam kegiatan industri (Raymond R. Tjandrawinata, 2016).

Perubahan di era Revolusi industri 4.0 menyebabkan terjadinya transformasi baru dan inovasi yang menyebar lebih cepat dibandingkan sebelumnya. Berbagai terobosan di berbagai lapangan kehidupan membawa dampak terhadap penurunan biaya produksi dan munculnya platform yang menyatukan serta mengonsentrasikan beberapa bidang keilmuan untuk meningkatkan produktifitas. Organisasi dalam perjalanannya mengalami perubahan-perubahan dari seluruh sistem produksi, manajemen dan tata kelola menuju efesiensi dan efektifitas .

Dewasa ini berbagai aktifitas di lingkungan masyarakat menjadi serba digitalisasi dan otomasi serta kegiatan tatap muka beralih ke on line. Toko-toko konvensional mulai ditinggalkan dan masyarakat memilih belanja on line. Sistem pembayaran baru melalui $e$ banking dan sebagian pekerjaan yang sudah berfungsi secara mantap di lingkungan masyarakat mulai hilang dan menyebabkan pemutusan hubungan kerja (PHK) (Susanto, 2015). Pekerja yang selama ini melayani pembayaran tunai, mulai hilang dengan diberlakukannya e-money. Begitu juga industri percetakan, seperti surat kabar, majalah dan buku mengalami penurunan dan media on line semakin berkembang serta digandrunggi masyarakat dalam mendapatkan informasi.

Perubahan di era Milinium 4.0, menuntut masyarakat dari berbagai sektor beradaptasi dengan otomasi dalam peningkatan produktifitas serta mewujudkan organisasi yang cerdas (smart factories), terstruktur melalui cyber physical system (sistem siberfisik), Internet untuk Segala (IoT), komputasi awan (cloud) dan komputasi kognitif. Semua kegiatan dalam masyarakat serba digital dan sistem siber-fisik mengawasi proses fisik, menciptakan salinan dunia fisik secara virtual serta membuat keputusan yang tidak terpusat.

Perkembangan teknologi informasi di Era Milinium 4.0 yang begitu cepat, memungkinkan hadirnya produk-produk dan jasa-jasa baru dengan harga murah serta cepat dalam memenuhi kebutuhan masyarakat. Model bisnis konvensional beralih ke online secara terintegrasi yang berbeda dengan kondisi sebelumnya. Paradigma bisnis bergeser dari owning menjadi sharing (kolaborasi), kondisi ini ditunjukan oleh perpindahan bisnis retail (toko fisik) ke dalam e commerce yang menawarkan kemudahan dalam berbelanja (Khasali, 2018).

Memasuki Milinium 4.0 terjadi perubahan dalam berbagai aspek kehidupan yang menekankan pola digital economy, artificial intelligence, big data, robotic, dan lain 
sebagainya (Sutrisno, 2018). Sistem organisasi perkantoran mulai berubah dan sebagian pekerjaan digantikan oleh program dan sistim pelayanan yang serba otomatis. Pekerjaanpekerjaan serba otomatis dan interaksi antar individu serta kelompok sosial lainnya mengalami perubahan tanpa batas dan perilaku berbasis media sosial semakin berkembang. Jasa pelayanan on line, seperti transportasi dalam bentuk taksi dan ojek on line serta pemesan on line lainnya semakin berkembang. Efesiensi dan efektifitas sebagai akibat dari perubahan sosial di era Revolusi Industri 4.0 mempunyai potensi dalam meningkatkan kesejahteraan masyarakat dengan penggerak ekosistem social enterprise. Perubahan tersebut juga memungkinkan terwujudnya kegiatan inkubasi dan akselerasi bagi social entrepreneurs serta investor dalam membangun jejaring serta kemitraan dalam berbagai kegiatan sosial ekonomi menuju perkembangan serta kesejahteraan masyarakat (Syamsuri \& Ishaq, 2010).

Melinium 4.0 pada prinsipnya bertujuan mencapai kestabilan distribusi barang/jasa dalam pemenuhan kebutuhan masyarakat secara efesien dan efektif. Sehubungan dengan hal itu, melalui Industri 4.0 memungkinkan pendataan kebutuhan masyarakat dan mengirim data tersebut ke produsen (Stalker, 2008). Kondisi tersebut memungkinkan produsen dapat memproduksi dalam jumlah yang tepat sesuai kebutuhant. Pelacakan produk barang/jasa secara transparansi dan akuntabel semakin mengarah ke layanan baru mengantikan pola-pola konvensional yang sudah mapang di lingkunang masyarakat, dengan mekanisme pengintegrasian produsen tanpa batas waktu serta tempat (Salle, 2016).

Bertitik tolak dari uraian tersebut, perubahan-perubahan di era Revolusi 4.0 memberi peluang baru dalam perkembangan individual dan masyarakat untuk memenuhi kebutuhan hidup. Revolusi Industri 4.0 bila tidak dicermati lebih lanjut, juga akan menimbulkan dampak negatif yang mengakibatkan terjadinya penurunan, pengerdilan serta keterlambatan perkembangan masyarakat. Kondisi ini selanjutnya menyebabkan terganggunya kepentingan dan kohesi sosial serta relasi yang sudah mapan di lingkungan masyarakat. Pengangguran, kerusakan alam dan berkembangnya hoax bila tidak mendapat perhatian, akan menganggu keberlangsungan hidup masyarakan di era globalisasi.

Revolusi 4.0 juga akan berdampak terhadap disrupsi teknologi, hukum, ekonomi, pendidikan, pertanian serta kehidupan social lainnya, termasuk sektor pendidikan. Penanggulangani disrupsi di bidang pendidikan dari berbagai jenjang serta tingkat memerlukan kreativitas pendidik dan tenaga kependidikan lainnya, termasuk di dalamnya 
Guru BK/Konselor Sekolah dalam menyiapkan peserta didik/konselee yang berkembang secara optimal di era milinium 4.0.

Sebagian besar siswa di sekolah dewasa ini, telah memanfaatkan teknologi informasi melalui internet dalam kehidupan sehari-hari. Apabila diamati lebih lanjut, sebagian siswa pengguna internet tersebut mengalami kesulitan melakukan aktivitas yang mendukung perkembangannya. Sebagian siswa mudah terpengaruh yang selanjutnya memunculkan tindakan pelanggar aturan, etika dan moral. Budaya Barat tidak jarang dijadikan acuan yang menyebabkan identitas serta jati diri Bangsa mengalami kemunduran.

Berdasarkan uraian tersebut menarik dibahas lebih lanjut melalui tulisan ini bagaimana inovasi dan kreativitas Guru Bk/Konselor Sekolah dalam menghadapi dampak revolusi industri 4.0. Pengungkapan permasalahan tersebut bermanfaat untuk merumuskan pola baru dalam pengembangan pelayanan bimbingan dan konseling sesuai dengan kebutuhan peserta didik di era milinium 4.0.

\section{B. Perubahan Sosial dan Guru BK/Konselor Sekolah di Era Milinium 4.0}

Perubahan sosial budaya di lingkungan masyarakat Indonesia begitu cepat, sehingga menimbulkan disruptif yang mendorong kesempatan baru bagi masyarakat melakukan berbagai aktifitas dalam pemenuhan kebutuhan hidupnya. Disrupsi dalam berbagai bidang di Era Milinium 4.0 akan ditentukan olah kualitas Sumber Daya Manusia (SDM) untuk meraih keberuntungan dalam memanfaatkan perkembangan yang ada tersebut. Revolusi industri 4.0 menghadirkan komputer super, kecerdasan buatan (artificial intelligency), sistem siber (cyber system), dan kolaborasi manufaktur (Lasmawan, n.d.). Elemen dari mellinium 4.0 terlihat seperti gambar sebagai berikut : 


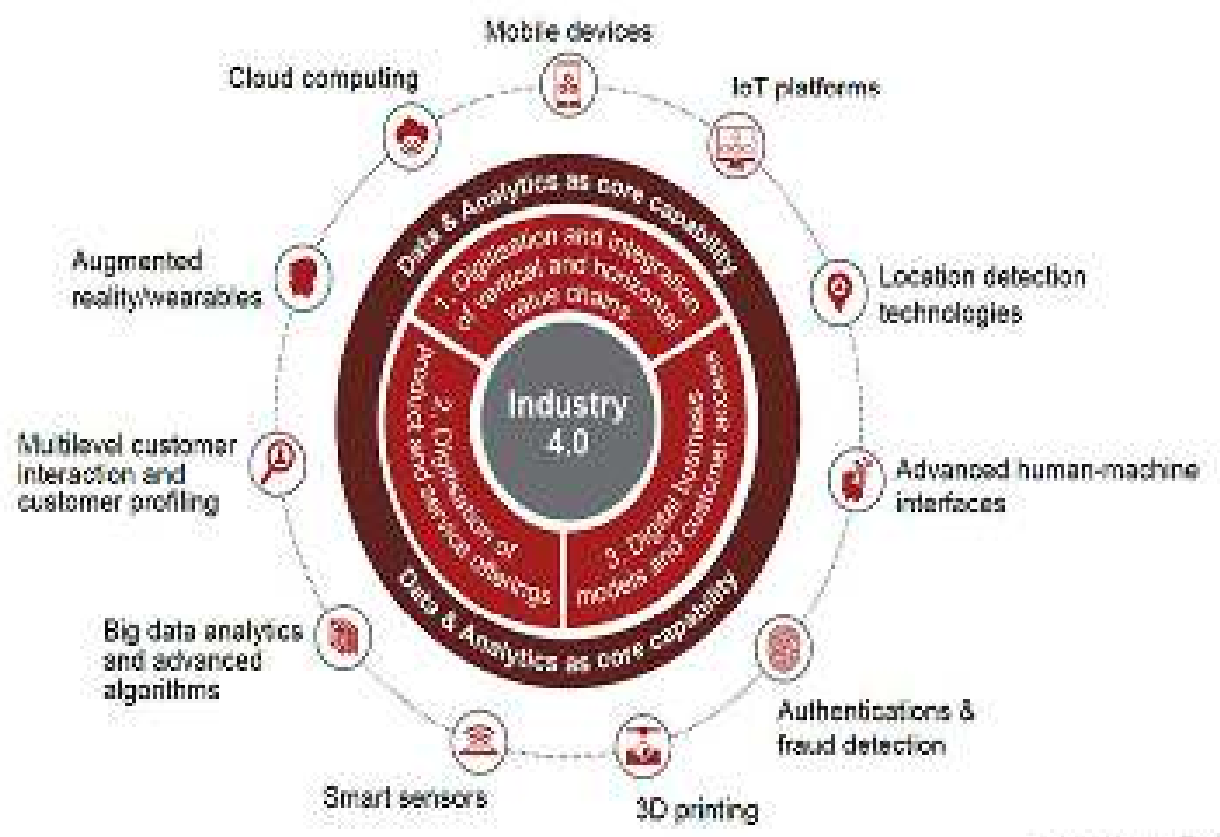

Sumber : https://mobnasesemka.com/apa-itu-industri-4-0

Apabila ditelusuri lebih lanjut, disruptif awalnya terjadi dalam kehidupan bisnis di dunia ekonomi yang menunjukan ketidak pastiaan karena dituntut berinovasi secara terus menerus mengikuti perkembangan masyarakat (Lasmawan, n.d.). Disrupsi telah membawa dampak ke dalam berbagai bidang kehidupan sosial dan budaya, termasuk bidang pendidikan. Pengelolaan pendidikan dihadapkan dengan birokrasi secara efektif dan efisien berbasis e governance. Selanjutnya perkembangan teknologi informasi juga memunculkan online learning dan pola relasi antar individu serta kelompok dalam dunia pendidikan mulai berubah. Perubahan pola relasi dalam masyarakat dipicu perkembangan media sosial yang memberi warna baru serta menimbulkan berbagai dampak di lingkungan peserta didik.

Perubahan di Era Mellinium 4.0 menuntut perubah di lingkungan pendidikan, yang mengadopsi kegiatan-kegiatan bercirikan penggunaan teknologi digital serta proses pembelajaran dengan sistem siber (cyber system). Kemampuan Guru BK/Konselor Sekolah mengikuti kemajuan teknologi serta mengembangan peserta didik menjadi sumber daya manusia yang dapat mengendalikan dampak negative serta mengambil peluang dari perkembangan teknologi dan informasi di era milinium 4.0 sangat diharapkan.

Peran utama Guru BK/Konselor Sekolah di Era Milinium 4.0, diharapkan dapat merumuskan berbagai jenis layanan bimbingan konseling dalam menyiapkan generasi milenial menjadi angkatan kerja yang kompetitif dan produktif. Sehubungan dengan hal itu, 
Guru BK/Konselor Sekolah diharapkan merumuskan road map pelaksanaan bimbingan dan konseling di sekolah yang mengacu kepada peta jalan (road map) pemerintah, berjudul Making Indonesia 4.0. Pemerintah Indonesia telah merumuskan road map yang menetapkan arah masa depan industri utama nasional,yaitu : industri makanan dan minuman, tekstil, otomotif, elektronik, dan kimia (Ridhwan et al., 2015).

Di sisi lain, Guru BK/Konselor Sekolah dalam pelaksanaan bimbingan dan konseling diharapkan dapat mengembangkan pola digital dalam pelaksanaan bimbingan dan konseling. Pengembangan pola digital tersebut diperlukan karena didukung oleh kemampuan generasi melinia sebagai pengguna internet di Indonesia mencapai 143 juta orang dan 49,5\% pengguna internet tersebut berusia 19-34 tahun.

Selanjutnya Guru BK/Konselor sekolah dituntut mendorong generasi milenial meningkatkan kapasitas agar berfungsi kelak sebagai pekerja yang menguasai sejumlah bahasa asing, agar dapat berinteraksi dengan masyarakat global. Di sisi lain Guru $\mathrm{BK} /$ Konselor Sekolah juga dituntut meningkatkan kompetensi peserta didik/konselee agar menguasai teknologi digital. Guru BK/Konselor Sekolah diharapkan dapat menyesuaikan kegiatan layanan bimbingan dan konseling dengan perubahan/ tantangan serta kebutuhan di Era Milinium 4.0. Perubahan tersebut diharapkan melahirkan generasi yang mampu berkompetisi dan produktif sesuai dengan kebutuhan masyarakat di Era Milinium 4.0.

Penyiapan Guru BK/Konselor Sekolah masa silam dibandingkan kebutuhan siswa/konselee di Era Milinia 4.0 jauh berbeda. Generasi millinia dihadapkan oleh perubahan aktifitas llayananan kantor/bank, penjualan jasa/barang berorientasi kertas beralih ke on line yang berlangsung secara terintegrasi dan otomatik. Perempuan selama ini bekerja di sektor domestic, sekarang meningkat untuk bekerja dalam kehidupan publik. Persaingan dengan kompetensi unggul dalam mewujudkan impian dan harapan menuntut Sumber Daya Manusia (SDM) yang memiliki disiplin yang tangguh menghadapi persoalan. (Firman, 2016).

Tantangan pemenuhan kebutuhan masyarakat di Era Milinium 4.0, menuntut Guru BK/Konselor Sekolah untuk terus belajar melalui jalur pra jabatan serta dalam jabatan, sehingga mampu menghadapi peserta didik generasi mellinial. Bagi Guru BK/Konselor Sekolah yang tidak berkesempatan mengembangkan diri akan terjadi kesenjangan dengan peserta didik/konselee. Kondisi ini akan menyebabkan kualitas layanan bimbingan dan konseling di Sekolah semakin tertinggal dibandingkan negara lain yang telah siap menghadapi perubahan era Milinium 4.0 tersebut. 
Kondisi di Era Milinium 4.0 memungkinkan terjadinya pembelajaran yang sarat dengan muatan pengetahuan berorientasi teknologi dan mengesampingkan muatan psikologis berkaitan sikap, moral serta hubungan sosial lainnya. Pola-pola pendidikan semacam itu akhirnya menghasilkan peserta didik yang tidak mampu berkompetisi dengan mesin. Diperkirakan berbagai permasalahan dialami individu, yang memerlukan pendekatan layanan bimbingan dan konseling berorientasi kepada peserta dididik menjadi primadona. Pendekatan layanan selama ini didominasi oleh Guru BK/Konselor Sekolah semakin berkurang dan pendidikan karakter serta literasi diharapkan menghasilkan peserta didik yang bijaksana memanfaatkan teknologi .

Pekerjaan Guru BK/Konselor Sekolah dituntut terlaksana secara profesional. Michael D. Bayles (1981) mengemukakan beberapa ciri profesi sebagai berikut: (1) perlunya training atau pendidikan untuk mempraktekkan profesi, (2) training atau pendidikan mencakup komponen intelektual yang memadai, (3) memiliki kemampuan yang telah terlatih memberikan layanan, (4) adanya sertifikasi atau lisensi untuk status professional, (5) adanya organisasi profesional yang menampung para anggota, serta (6) adanya otonomi dalam melaksanakan pekerjaan (Firman, 2009).

Keterampilan peserta didik yang diharapkan di Era Milinium 4.0, yaitu : keterampilan berpikir kritis dan pemecahan masalah (critical thinking and problem solving skill), (2) keterampilan komunikasi dan kolaboratif (communication and collaborative skill. (3) keterampilan berpikir kreatif dan inovasi (creativity and innovative skill). (4) literasi teknologi informasi dan komunikasi (information and communication technology literacy), (5) literasi teknologi informasi dan komunikasi (TIK), (6) contextual learning skill, (7) literasi informasi dan media (information and media literacy) (Ratna Hidayah1, Moh. Salimi2, 2017).

Dengan demikian Guru BK/Konselor Sekolah di Era Milinium 4.0 diharapkan bertanggung jawab menyiapkan peserta didik/konselee berkompetensi dan mengambil peluang dalam perubahan di era Revolusi Industri 4.0. Sehubungan dengan hal itu, Guru BK/Konselor Sekolah dituntut menguasai dan memanfaatkan teknologi digital dalam pelaksanaan layanan bimbingan dan konseling di Era Melinium 4.0.

\section{Generasi Millenial dan Permasalahannya}

Generasi mellinial disebut juga dengan generasi Y, yang merupakan generasi lahir kira-kira tahun 1981 sampai1994, sebagian penulis ada juga menyebutkan lahir dari tahun 
1981 sampai tahun 2000 an. Generasi mellinial sebagian besar menggunakan teknologi komunikasi instan dalam kehidupannya, seperti: e-mail, SMS (Short Message Service), instan messaging, dan media social dan sebagian besar menyukai game on-line.

Generasi mellinial dewasa ini mencapai 50 persen di dunia kerja dan diperkirakan tahun 2030 berjumlah sebanyak 75 persen menduduki lapangan kerja global. Generasi mellinial berbeda dengan generasi sebelumnya, yaitu generasi X. Generasi X lahir 1965 sampai 1980, yang aktifitas mereka menggunakan teknologi yang belum meluas, karena lahir diawal-awal kenal PC, cable TV dan disket. Begitu juga generasi sebelumnya yang lahir tahun 1946 sampai 1965, disebut baby boomers. Generasi ini dipandang sebagai penentu karena sudah mulai menerima perubahan dengan hadirnya musik rock and roll dan celana cut bray yang menjadi mode mengiasai kehidupannya.

Generasi mellinial memiliki kelebihan dibandingkan generasi sebelumnya, yaitu (1) multitasking, melakukan berbagai kegiatan dalam waktu bersamaan dan tetap mengejar deadline. Perkembangan teknologi membuat generasi mellinial untuk bekerja serba cepat dalam waktu bersamaan yang harus diselesaikannya, (2) kreativitas yang ada dihargai dan mengutamakan persamaan. Perbedaan usia serta kelas sosial lainnya tidak dipedulikan dan penghargaan utama diberikan kepada ide dan kreativitas, (3) kritis dan tidak mau menerima apa adanya, generasi mellinial berusaha membandingkan data kondisi nyata dengan dunia maya, selanjutnya akan melahirkan pemahaman baru yang berbeda dengan sebelumnya, serta (4) berkontribusi dengan cara berbeda.

Di sisi lain, generasi mellinial juga memiliki kelemahan, yaitu : (1) berorientasi kepada produk dan berkeinginan serba instan. Generasi mellinial berpandangan bahwa semua pekerjaan dipermudah oleh teknologi yang dapat diselesaikan serba cepat. Generasi mellinial kurang menghargai proses, kurang memiliki semangat juang dan kurang tangguh apabila dihadapkan dengan masalah, (2) kurang mematuhi etika yang sudah mapan, generasi mellinial berpandangan semua aktifitas dapat dipercepat oleh teknologi dan mengabaikan etika yang seharusnya mereka patuhi di masyarakat, (3) cenderung permisif dan terbuka terhadap perubahan. Generasi mellinial tidak jarang kebablasan dalam menginterpretasi sesuatu yang selama ini dianggap tabu dan akhirnya menjadi hal yang biasa, (4) memiliki keterampilan sosial yang rendah dan terkesan kurang beretika, generasi mellinial tidak terlatih berkomunikasi secara langsung dan terkesan kurang peduli dengan orang yang berasa di sekitarnya. 
Berdasarkan uraian tersebut terlihat karakteristik generasi Millinial, yaitu (1) rasa percaya diri, (2) optimistis, (3) ekspresif, (4) bebas, dan (5) menyukai tantangan (Oktavianus, 2017). Genrasi mellinial menjalani kehidupan sehari-hari yang terbuka dengan pembaharuan dan ingin tampil beda, kreatif, menyukai suasana kerja yang santai serta mampu mengerjakan beberapa tugas secara bersamaan, peduli terhadap gaya dan cepat beradaptasi dengan teknologi.

Permasalahan fondamental dialami generasi melinial, yaitu gampang bosan dan kurang memiliki loyalitas terhadap pekerjaan (Suryadi, 2015;M. Subandowo, 2017). Di sisi lain, sebagian generasi milinial adiksi gadget, kurang fokus dalam belajar, mudah terganggu dan emosinya meledak-meledak, pornografi, pergaulan bebas dan memunculkan degradasi moral dan kebebasan bergaul (Munir, 2018).

Kelemahan tersebut membuat generasi millinial rentan akan social media harassment hingga menimbulkan persoalan cybercrime yang memberikan pengaruh negatif terhadap kematangan perkembangan kognitif generasi muda. Generasi mellinial terikat dengan media sosial yang tidak hanya berperan sebagai online interaction akan tetapi juga berperan sebagai wahana komunikasi politik (Retnayu Prasetyanti, 2017).

Dengan demikian dapat disimpulkan generasi mellinial memiliki kelebihan yang dapat melakukan berbagai kegiatan dalam waktu bersamaan, kreatif dan mengutamakan persamaan, kritis dan berkontribusi dengan berbagai cara. Di sisi lain, generasi mellinial memiliki kelemahan yang tidak berorientasi kepada proses dan mengutamakan produk, kurang mematuhi etika, permisif terhadap perubahan dan memiliki keterampilan sosial yang rendah dan terkesan kurang beretika, tidak terlatih berkomunikasi secara tatap muka dan kurang peduli dengan penderitaan orang lain.

\section{Inovosi dan Kreatifitas yang Diperlukan dari Guru Bk/Konselor Sekolah di Era Milinium 4.0}

Peserta didik di Era melinium 4.0 yang dikenal dengan generasi mellinium, mempunyai karakteristik berbeda dengan generasi sebelumnya. Generasi millenial telah berpengalaman menggunakan teknologi digital untuk kegiatan membaca berita di media cetak, elektronik, digital, jejaringan sosial dan berita lainnya, mendengarkan dan merekam musik, melihat/membuat dan mempublikasikan berbagai pesan. Di sisi lain, generasi millenial juga telah terbiasa hidup bertoleransi, berani mengambil resiko, menghargai 
waktu, mencari informasi di seluruh dunia dan menggunakan tautan hypertext untuk mempelajari sesuatu (Syamsuri \& Ishaq, 2010).

Karakteristik generasi millenial, antara lain : keinginan memegang kendali, tidak mau mengikat diri dengan hal bersifat sekunder, kurang menyukai duduk di dalam ruangan untuk belajar/bekerja, menggunakan teknologi untuk belajar/ bekerja dengan kreatif, membutuhkan berbagai metode dalam menyelesaikan berbagai persoalan dan tantangan, berorientasi dengan kelompok dan kegiatan sosial, melakukan kegiatan belanja dan bermain bersama. Mengidentifikasi teman-teman sesuai kebutuhan secara on line dan bergabung dalam komunitas tertentu, bergaul dengan rekan-rekan di seluruh dunia secara on line (Putra, 2016).

Bertitik tolak dari uraian tersebut, kebutuhan generasi mellinial akan layanan bimbingan dan konseling di sekolah berbeda dengan generasi sebelumnya. Program dan kegiatan bimbingan dan konseling dituntut beradaptasi sesuai dengan karakteristik serta kebutuhan generasi mellinial. Program dan model layanan bimbingan dan konseling yang dibutuhkan lebih banyak menggunakan teknologi digital (online). Model dan pendekatan layanan bimbingan dan konseling tidak bisa diberlakukan sama generasi sebelumnya. Kreatifitas dan inovasi Guru BK/Konselor Sekolah merumuskan pendekatan dan model layanan bimbingan dan konseling sesuai kebutuhan generasi mellenium sangat diharapkan.

Di sisi lain, layanan bimbingan dan konseling di sekolah memerlukan dukungan sarana dan prasarana yang memadai. Guru BK/Konselor Sekolah dituntut memiliki kemampuan melaksanakan metode/teknik pelayanan berorientasi kepada peserta didik/konselee, guna menciptakan suasana yang menyenangkan yang diperlukan. Pelaksanaan layanan yang mengembangkan cara berpikir tinggi/higher order thinking skills (HOTS) akan menghasilkan peserta didik/Konselee berkemampuan berpikir kritis, terampil berkomunikasi, berkolaborasi, berpikir kreatif dan percaya diri.

Guru BK/Konselor Sekolah diharapkan mampu mengarahkan peserta didik/konselee berpikir kritis, analistis dalam penyelesaian masalah yang mereka hadapi. Layanan bimbingan dan konseling merupakan layanan pendidikan yang pada hakekatnya membantu perkembangan optimal dari peserta didik. Guru BK/Konselor Sekolah dalam pelaksanaan tugasnya, memerlukan kesiapan berbagai strategi dan pendekatan untuk melaksanakan layanan bimbingan dan konseling berorientasi kepada keterampilan berpikir tingkat tinggi. 
Strategi yang dapat dilakukan Guru BK/Konselor Sekolah dengan berbagai jenis layanan serta bimbingan, menghadapi peserta didik/konselee di Era Milinium 4.0 yaitu : (1) mendorong dan memfasilitasi generasi mellinial menyampaikan ide-ide kreatif dan inovatif, (2) memfasilitasi generasi mellinial untuk memodifikasi ide-ide dalam melahirkan inavasi, (3) memberikan umpan balik serta (4) menggunakan informasi dan pengalaman yang ada untuk merumuskan pendekatan/strategi serta model layanan bimbingan dan konseling yang diperlukan.

Dewasa ini masih ditemukan, sebagian Guru BK/Konselor Sekolah belum menyadari perubahan dengan semua elemen yang ditimbulkan oleh perkembangan teknologi informasi di era Milinium 4.0. Kadang-kadang perubahan dan perkembangan yang terjadi masih menjadi bahan perdebatan dan tidak dijadikan dasar pijakan dalam pengembangan generasi muda/peserta didik memiliki kemampuan berkompetisi dan mengambil peluang di era Milium 4.0. Perubahan-perubahan di era milinium 4.0, menuntut Guru BK/Konselor Sekolah dan peserta didik beradaptasi dengan cara mengubah perilaku dan pola bekerja, hingga tuntutan keterampilan yang diperlukan masyarakat terpenuhi.

Penyiapan peserta didik/konselee menghadapai tantangan dan mengambil peluang, merupakan sasaran utama yang harus dilakukan dalam pelaksanaan bimbingan dan konseling di sekolah. Guru BK/Konselor Sekolah dituntut merumuskan program bimbingan dan konseling yang relevan dengan kebutuhan generasi mellinia. Layanan bimbingan dan konseling akan lebih berarti apabila kegiatan yang dilaksanakan sesuai dengan kebutuhan, dengan pertimbangan utama konten bersifat spesifik, tepat sasaran, praktis serta dapat diaplikasikan dalam kehidupan nyata. Kebutuhan utama yang mereka perlukan adalah bagaimana upaya menemukan dan apa yang mereka perlukan untuk itu.

Program bimbingan dan konseling yang telah dirumuskan sesuai dengan kebutuhan generasi mellinia, menuntut kemampuan Guru BK/Konselor Sekolah menggunakan teknologi sebagai pendukung pelaksanaan program bimbingan dan konseling tersebut. Generasi mellinial sangat sensitif dengan penggunaan teknologi tinggi dan tidak jarang membuat Guru BK/Konselor merasa terganggu, karena cepat dan dinamiknya informasi yang mereka peroleh dari satu waktu ke waktu berikutnya. Tidak jarang ditemui generasi mellinial terlalu banyak aktifitas dan sangat mudah menerima informasi dari berbagai sumber. Kadang-kadang mereka merasa tidak menemukan mafaat dari layanan bimbingan dan konseling yang ada karena kurang sesuai dengan kebutuhannya. 
Pemenuhan kebutuhan layanan bimbingan dan konseling sesuai dengan kebutuhan generasi melinial, menuntut sekolah menyediakan perangkat lunak, infrastruktur serta dukungan teknis dalam pelaksanaan layanan bimbingan dan konseling secara profesional. Guru BK/Konselor Sekolah dituntut menguasai berbagai teknik dan pendekatan yang dapat melayani keberagaman serta mendorong perkembangan kemampuan berfikir dalam penyelesaian permasalahan serta berprestasi dengan tidak mengabaikan nilai dan moral yang ada.

Generasi millinial sebagian besar berperilaku connected, creative, berpikir out of the box dan percaya diri dalam berpendapat. Teknologi yang mereka gunakan secara terintegrasi tidak paralel secara otomatis meransang dan mendorong tumbuhkembangnya dimensi moral serta sosial psikologis. Teknologi informasi yang digunakan mentransfer kognisi dan skill tanpa harus tatap muka pada seluruh jenjang pendidikan yang mereduksi transfer dimensi moral dan sosial psikologis.

Di Era Milinium 4.0, faktor produksi terletak dengan kapasitas pengelolaan informasi dan pengetahuan, yang dibuktikan oleh kegiatan berjualan tanpa harus mempunyai toko dan berbisnis taksi tanpa harus mempunyai mobil. Perkembangan jejaringan sosial dan teknologi informasi membuat hasrat belanja daring menjadi energi baru dalam masyarakat. Berbelanja daring tidak hanya efektif tetapi juga menjanjikan prestise serta gaya hidup generasi mellinial. Pergeseran hubungan social yang dominat menggunakan teknologi informasi secara otomatis akan menumbuhkan potensi konflik serta pergeseran kebutuhan pasar tenaga kerja. Kondisi ini diperkirakan akan menimbulkan kesenjangan penggunaan teknologi baru dengan kematang sosial berlandasan kepada moral serta etika yang sudah mapan di masyarakat. Kondisi ini memerlukan kreatifitas Guru BK/Konselor sekolah mengidentidikasi serta merumuskan pendekatan konseling yang sesuai dengan kebutuhan generasi mellinial.

Dengan demikian dapat disimpulkan, Guru BK/Konselor Sekolah dituntut menyiapkan peserta didik/konselee menghadapai tantangan dan mengambil peluang, merumuskan program bimbingan dan konseling yang relevan dengan kebutuhan generasi mellinia.

\section{E. KESIMPULAN}

Berdasarkan uraian terdahulu dapat disimpulkan sebagai berikut :

1. Guru BK/Konselor Sekolah di Era Milinium 4.0 dituntut menyiapkan peserta didik/konselee berkompetensi dan mengambil peluang dalam perubahan di era 
Revolusi Industri 4.0. Guru BK/Konselor Sekolah dituntut menguasai dan memanfaatkan teknologi digital dalam layanan bimbingan dan konseling di Era Melinium 4.0.

2. Generasi mellinial memiliki kelebihan untuk melakukan berbagai kegiatan dalam waktu bersamaan, kreatif dan mengutamakan persamaan, kritis dan berkontribusi dengan berbagai cara. Kelemahan generasi mellinial, yaitu tidak berorientasi kepada proses dan mengutamakan produk, kurang mematuhi etika, permisif terhadap perubahan dan memiliki keterampilan sosial yang rendah dan terkesan kurang beretika, tidak terlatih berkomunikasi secara tatap muka dan kurang peduli dengan penderitaan orang lain.

3. Program dan model layanan BK yang dibutuhkan generasi mellinial lebih banyak menggunakan teknologi digital (online). Guru BK/Konselor Sekolah dituntut memiliki kemampuan melaksanakan metode/teknik pelayanan berorientasi kepada peserta didik/konselee. Strategi yang dapat dilakukan, yaitu : (1) mendorong dan memfasilitasi generasi mellinial menyampaikan ide-ide kreatif dan inovatif, (2) memfasilitasi generasi mellinial untuk memodifikasi ide-ide dalam melahirkan inavasi, (3) memberikan umpan balik serta (4) menggunakan informasi dan pengalaman merumuskan pendekatan/strategi serta model layanan bimbingan dan konseling yang diperlukan.

\section{Daftar Kepustakaan}

Firman. (2009). Tanggung Jawab Profesi Guru dalam Era Teknologi Informasi. Jurnal Ilmiah Ilmu Pendidikan, IX(1), 29-47.

Firman, F. (2016). Peranan Psikologi dan Konseling dalam Peningkatan Kualitas Sumber Daya Manusia (SDM) Menuju Kesejahteraan Masyarakat Ekonomi Asean, 2(Asean Psychology an counseling 2016), 5-9.

Hoover, Eric. (2009). The Millennial Muddle: How stereothyping students became a thriving industry and a bundle of contradictions. The chronicle of higher education. Retrieved 18 April 2015

Horovits, Bruce. (2012). After Gen X, Millennials, what should next generation be?. USA Today. Retrieved 18 April 2015

Lasmawan, W. (n.d.). Disruption Era dan Dampaknya Bagi Pengembangan Kurikulum.

M. Subandowo. (2017). Peradaban dan Produktivitas dalam Perspektif Bonus Demografi serta Generasi Y dan Z. Sosiohumanika: Jurnal Pendidikan Sains Sosial Dan Kemanusiaan, 10(2), 191-208. 
Munir, M. (2018). John Naisbitt, Et. All. High Tech High Touch (Jakarta: Pustaka Mizan, 2002). Lihat juga Zuhal, Visi Iptek Memasuki Milenium III (Jakarta: Universitas Pendidikan Indonesi Pers, 2000). 1, 7(1).

Padmo, D. (2005). Teknologi Pembelajaran: Peningkatan Daya Saing Sumber Daya Manusia. Universitas Terbuka.

Putra, Y. S. (2016). Theoritical Review:Teori Perbedaan Generasi, (2016), 302.

Ratna Hidayah1, Moh. Salimi2, T. S. S. U. (2017). 1* , 2 , 3. JURNAL TAMAN CENDEKIA, $1(2), 656-663$.

Raymond R. Tjandrawinata. (2016). Industri 4.0: Revolusi Industri Abad Ini Dan Pengaruhnya Pada Bidang Kesehatan, (February).

Retnayu Prasetyanti, S. P. (2017). Generasi Millennial Dan Inovasi Jejaring Demokrasi Teman Ahok. Jurnal Polinter, 3(1), 44-52.

Ridhwan, M. M., Wicaksono, G., Nurliana, L., Bary, P., Suryani, T. ., \& Satyanugroho, R. (2015). Analisis Daya Saing Dan Strategi Industri Nasional Di Era Masyarakat Ekonomi Asean Dan Perdagangan Bebas, 111. https://doi.org/10.1016/S0007-1935(17)35243-0

Salle, A. (2016). Makna transparansi dalam pengelolaan keuangan daerah. Jurnal Kajian Ekonomi Dan Keuangan Daerah, 1-19.

Stalker, P. (2008). Millrnium Development Goals. Jakarta.

Sutrisno. (2018). Ancaman Keamanan Era Milenial dan Tekstur Pendidikan Tinggi (Sebuah Pembacaan Sosiologik). Jurnalptik.Id, 12, 15-27. Retrieved from http://jurnalptik.id/index.php/JIK/article/download/20/16

Syamsuri, H. A. S., \& Ishaq. (2010). Makalah : Guru, Generasi Z, dan Pembelajaran Abad 21. Repositori Unismuh.ac.id, 1-15. 
